Review Article

\title{
REVIEW OF IPOMOEA PES-TIGRIDIS L.: ETHNO BOTANICAL CHARACTERISTICS, PHARMACOLOGICAL ACTIVITIES
}

\author{
N. VENKATESHAN ${ }^{2}$, M. SUBRAMANIYAM ${ }^{1}$, M. SANTHANAKUMAR ${ }^{1}$ \\ 1Department of Pharmacology, Arulmigu Kalasalingam College of Pharmacy, Krishnan Koil 626126, 'Department of Pharmaceutical \\ Chemistry, Arulmigu Kalasalingam College of Pharmacy, Krishnan Koil 626126
}

Email: subramaniyampharm@gmail.com

Received: 10 Jul 2018, Revised and Accepted: 07 Sep 2018

\begin{abstract}
Nowadays there is a need for scientific justification of plants that have been used in traditional medicine because of loss of information, improvement of therapy and deforestation that is taking place. The majority of the natural products are compounds biosynthetically derived from primary metabolites and are generally categorized as secondary metabolites. These are the major sources of the pharmaceutical industry to discover novel drugs. The basis for interest in natural product chemistry serves as a lead compound for newer drugs, give as much information on possible mechanism and thus on the molecular origin and basis of diseases. Natural products are permanent challenges with respect to total synthesis and stimulate the development of new reagents and reactions. The present study has been taken up to review one of the ethno medicinal significant of Ipomoea pes-tigridis L plant belonging to the family convolvulaceae. The ethno medical information of the plant reveals that the herb Ipomoea pes-tigridis Linn was used as an antidote to dogbite, boils and carbuncles, the leaves were applied as a poultice for boils, carbuncles and sores. The root of this plant was found to possess purgative action. The phytochemical studies on the leaves have been reported for the presence of carbohydrates, proteins and resins.
\end{abstract}

Keywords: Ipomoea pes-tigridis L, Physico-chemical characters, Phytochemical Screening

(C) 2018 The Authors. Published by Innovare Academic Sciences Pvt Ltd. This is an open access article under the CC BY license (http://creativecommons.org/licenses/by/4.0/) DOI: http://dx.doi.org/10.22159/ijcpr.2018v10i6.30968

\section{INTRODUCTION}

Ipomoea pes-tigridis is a spreading or twinning herb. It is herbaceous annual, almost Throughout India ascending up to $4000 \mathrm{ft}$, plains from the coast, to $750-900 \mathrm{~m}$, often in arable lands [1]. The climber flowers throughout the year. The leaves are hairy, palmately 5-9 lobed; flowers are while and funnel-shaped. The leaf consists of a thick, abaxially hanging midrib, thick, squarish epidermal cells, and parenchymatous ground tissue. The vascular strand is single bowlshaped and bicollateral and surrounded by hyaline bundles of sheath cells. Calcium oxalate crystals of druses or sphaero crystals are located in the spongy parenchyma. The epidermal cells appear amoeboid in outline and are wide with thick, wavy anticlinal walls. The stomata are predominantly paracytic type. The lateral veins are thin and straight and form reticulate venation. The vein-islets are rectangular or polygonal. The vein terminations are curved and are undulate. The distal part of the petiole is semi-circular along the abaxial side and has shallow median groove on the adaxial side and consists of parenchymatous, vascular strand having xylem and phloem elements. The evaluation of powder under microscopy showed the presence of unicellular and unbranched non-glandular epidermal trichomes, subsessile glandular trichomes, peltate-type glands are seen detached from the epidermis [2, 3].

Plant profile [4-6]

Biological source: Ipomoea pes-tigridis Linn.

Family: Convolulaceae

Systematic position

Subkingdom: Tracheobionta

Super division: Spermatophyta

Division: Magnoliophyta

Class: Magnoliopsida

Subclass: Asteridae

Order: Solanales
Family: Convolvulaceae

Genus: Ipomoea L.

Species: pes-tigridis $L$.

Vernacular names [4]

English: Morning glory, Tiger foot.

Hindi: Ghiabati, Panch-patri.

Malayalam: Pulichuvadu.

Sanskrit: Arishta, Shankine.

Tamil: Pulichovadi, Punaikkirai.

Telugu: Chikunuvvu, Mekama-dugu, Puritikada.

Bengali: Langulilata.

Oriya: Bilaipado.

Preliminary phytochemical screening [7-9]

1. Test for sterols

The powdered leaf was first extracted with petroleum ether and evaporated to a residue. Then the residue was dissolved in chloroform and tested for sterols.

\section{a. Salkowski's test}

A few drops of concentrated sulphuric acid were added to the above solution, shaken well and set aside. The lower chloroform layer of the solution turns red in color if there is a presence of sterols.

\section{b. Liebermann-Burchard's test}

To the chloroform solution, a few drops of acetic anhydride and $1 \mathrm{ml}$ of concentrated sulphuric acid were added through the sides of the test tube and set aside for a while. At the junction of two layers, a brown ring will be formed, and the upper layer turns green if there are sterols. 

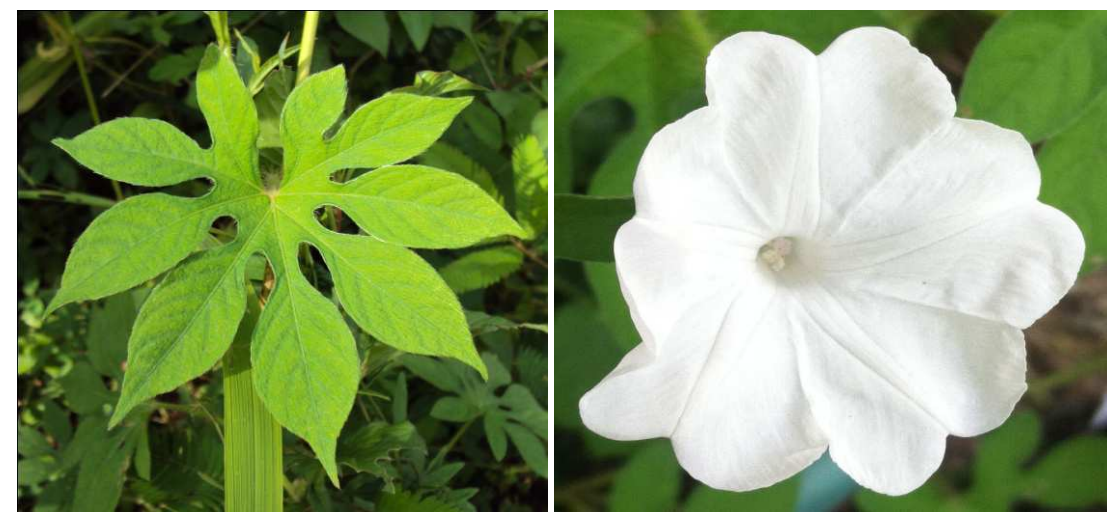

Fig. 1: a) Ipomoea pes-tigridis leaf, b) Ipomoea pes-tigridis flower

\section{Test for terpenoids}

A little of the powdered leaf was extracted with chloroform and filtered. The filtrate was warmed gently with tin and thionyl chloride. A pink solution will appear if there are terpenoids.

\section{Test for carbohydrates}

\section{a. Molisch's test}

The aqueous extract of the powdered leaf when treated with an alcoholic solution of

$\alpha$-naphthol in the presence of sulphuric acid showed a purple colour if there are carbohydrates.

\section{b. Fehling's test}

The aqueous extract of the powdered leaf was treated with Fehling's solution I and II and heated on a boiling water bath for half an hour. A red precipitate will be obtained if there are free reducing sugars.

\section{Test for flavonoids}

\section{a. Shinoda's test}

A little of the powdered drug was heated with alcohol and filtered. To the test solution, magnesium turnings and few drops of concentrated hydrochloric acid were added and boiled for five minutes. A red colour will be obtained if there are flavonoids.

\section{b. Alkali test}

To the small quantity of test solution, $10 \%$ aqueous sodium hydroxide solution was added. A yellow-orange color will be produced which will indicate the presence of flavones.

\section{c. Acid test}

To the small quantity of test solution, few drops of concentrated sulphuric acid were added. A yellow-orange color will be obtained which will indicate the presence of flavonols.

\section{Test for proteins}

\section{a. Millon's test}

A small quantity of aciduous-alcoholic extract of the powdered drug was heated with Millon's reagent. A white precipitate turned red on heating will indicate the presence of proteins.

\section{b. Biuret test}

To one portion of aciduous-alcoholic extract of the powdered drug 1 ml of $10 \%$ sodium hydroxide solution was added, followed by one drop of dilute copper sulphate solution. A violet color will be obtained which indicates the presence of proteins.

\section{Test for alkaloids}

About $2 \mathrm{~g}$ of the powdered material was mixed with $1 \mathrm{~g}$ of calcium hydroxide and $5 \mathrm{ml}$ of water into a smooth paste and set aside for 5 min. It was then evaporated to dryness in a porcelain dish on a water bath. To this $200 \mathrm{ml}$ of chloroform was added, mixed well and refluxed for half an hour on a water bath. Then it was filtered, and the chloroform was evaporated. To this $5 \mathrm{ml}$ of dilute hydrochloric acid was added followed by $2 \mathrm{ml}$ of each of the following reagents. If the colored precipitates are formed for the following reagents will indicate the presence of alkaloids.

a) Mayer's Reagent-Cream precipitate

b) Dragendorff's Reagent-Orange brown precipitate

c) Hager's Reagent-Yellow precipitate

d) Wagner's Reagent-Reddish brown precipitate

\section{9. (i) Test for anthraquinone glycosides}

\section{a. Borntrager's test}

The powdered leaf was boiled with dilute sulphuric acid, filtered and to the filtrate, benzene was added and shaken well. The organic layer was separated to which ammonia solution was added slowly. Pink color will be observed in the ammoniacal layer which shows the presence of anthraquinone glycosides.

\section{b. Modified borntrager's test}

About $0.1 \mathrm{~g}$ of the powdered drug was boiled for 2 min with dilute hydrochloric acid and few drops of ferric chloride solution, filtered while hot and cooled. The filtrate was then extracted with benzene and the benzene layer was separated. An equal volume of dilute ammonia solution was added to the benzene extract. A pink color will be observed in an ammoniacal layer which shows the presence of anthraquinone glycosides.

\section{(ii) Test for cardiac glycosides (for deoxysugar)}

\section{Keller kiliani test}

About $1 \mathrm{~g}$ of the powdered leaf was boiled with $10 \mathrm{ml}$ of $70 \%$ alcohol for $2 \mathrm{~min}$, cooled and filtered. To the filtrate, $10 \mathrm{ml}$ of water and 5 drops of a solution of lead subacetate were added and filtered, evaporated to dryness. The residue was dissolved in $3 \mathrm{ml}$ of glacial acetic acid. To this 2 drops of ferric chloride solution was added. Then $3 \mathrm{ml}$ of concentrated sulphuric acid was added to the sides of the test tube carefully and observed. A reddish brown layer will be observed which indicates the presence of deoxysugars of cardiac glycosides.

\section{(iii) Test for cyanogenetic glycosides}

A small quantity of the powder was placed in a stoppered conical flask with just sufficient water to cover it. A sodium picrate paper strip was inserted through the stopper so that it was suspended in the flask and it was set aside for $2 \mathrm{~h}$ in a warm place. A brick red color produced on the paper will indicate the presence of cyanogenetic glycosides. 


\section{Test for saponins}

\section{Foam test}

About $0.5 \mathrm{~g}$ of the powdered drug was boiled gently for 2 min with $20 \mathrm{ml}$ of water and filtered while hot and allowed to cool. $5 \mathrm{ml}$ of the filtrate was then diluted with water and shaken vigorously. Frothing if produced indicates the presence of saponins.

\section{Test for tannins}

A small quantity of the powdered drug was extracted with water. To the aqueous extract, few drops of ferric chloride solution were added. A bluish-black color if produced will indicate the presence of tannins.

\section{Quantitative estimation of phytoconstituents [10]}

The quantitative estimations are important since they help in finding the amount of secondary metabolites present in the crude extracts which can be expressed as equivalent to a standard drug. This helps us to find which secondary metabolites are responsible for the pharmacological activity.

\section{Pharmacological activities}

Analgesic activity $[12,13]$

The study was conducted by Tail Flick Response Method and Acetic-acid Induced Writhing in Mice. The experiment showed the ethanolic leaf extract of Ipomoea pes-tigridis has significant activity with a dose-dependent significant reduction of writhes using plate reaction time. It showed that the I. pes-tigridis extract is capable of inhibiting non-inflammatory reactions as well as inflammatory pain. Analgesic and neuropharmacological effect of Ethyl acetate extract of I. pes-tigridis was carried on Albino mice by Hotplate method, Hole cross test and Open field test and these tests showed significant activities.

Table 1:

\begin{tabular}{|c|c|c|}
\hline S. No. & Test & Results \\
\hline \multirow[t]{3}{*}{1.} & TEST FOR STEROLS & \\
\hline & a. Salkowski's test & + \\
\hline & b. Libermann-Burchard's test & + \\
\hline \multirow[t]{2}{*}{2.} & TEST FOR CARBOHYDRATES & \\
\hline & a. Molisch's test & + \\
\hline \multirow[t]{3}{*}{3.} & TEST FOR PROTEINS & \\
\hline & a. Millon's test & + \\
\hline & b. Biuret test & + \\
\hline \multirow[t]{2}{*}{4.} & TEST FOR ALKALOIDS & \\
\hline & b. Dragendroff's reagent & - \\
\hline \multirow[t]{7}{*}{5.} & TEST FOR GLYCOSIDES & \\
\hline & a. Anthraquinone glycosides & \\
\hline & i) Borntrager's test & - \\
\hline & ii) Modified Borntrager's test & - \\
\hline & b. Cardiac glycosides & \\
\hline & i) Keller Killiani test & - \\
\hline & c. Cyanogenetic glycosides & - \\
\hline \multirow[t]{2}{*}{6.} & TEST FOR SAPONINS & \\
\hline & Foam test & - \\
\hline \multirow[t]{2}{*}{7.} & TEST FOR TANNINS & \\
\hline & $\mathrm{FeCl}_{3}$ test & + \\
\hline \multirow[t]{2}{*}{8.} & TEST FOR FLAVONOIDS & \\
\hline & a. Shinoda test & + \\
\hline 9. & TEST FOR TERPENOIDS & + \\
\hline
\end{tabular}

Table 2: Physico-chemical characteristics of leaf and stem of Ipomoea pes-tigridis [11]

\begin{tabular}{llll}
\hline S. No. & Physico-chemical parameters & Leaves (\%) \\
\hline 1 & Loss on drying & 10.59 & Stems (\%) \\
2 & Total Ash & 10.03 & 8.37 \\
3 & Acid Insoluble ash & 0.63 & 12.21 \\
4 & Water soluble ash & 4.80 & 0.04 \\
5 & Alcohol soluble extractive & 6.52 & 7.70 \\
6 & Water soluble extractive & 12.58 & 4.57 \\
\hline
\end{tabular}

\section{Antimicrobial assay [14]}

The antimicrobial activity of I. pes-tigridis was evaluated by disc diffusion method against selective gram-positive bacteria Staphylococcus aureus and Bacillus subtilis and gram-negative bacteria Escherichia coli, Pseudomonaus aeruginosa, Salmonella typhi, Salmonella paratyphi, and Vibrio cholera. The ethyl acetate extract and $\mathrm{N}$-hexane extract of I. pes-tigridis showed prominent activity against $S$. aureus, $B$. subtilis and V. cholera.

\section{Antioxidant study $[15,16]$}

Antioxidant effect was conducted with DPPH method. The extract showed a dose-dependent radical scavenging effect in DPPH assay.

\section{Anti-acne activity and Anti-inflammatory activity [17]}

This study states that the $2 \%$ herbal hydrogel loaded with the crude methanol extract of aerial parts of I. pes-tigridis are effective for acne. The formulation was evaluated for various parameters like organoleptic characters, $\mathrm{pH}$, skin irritation test by multiple compartment patch, microbial contamination, extrude ability, spreadability, drug content, diffusion studies using pig skin, accelerated stability studies, drug excipient interaction studies by FTIR, in vitro anti-acne and in vivo anti-inflammatory activity. The formulated hydrogel passed all the evaluation parameters. The hydrogel was olive green in color and had an excellent fragrance. The diffusion studies revealed that the drug release was in controlled release form. The accelerated stability studies revealed that formulation was stable at room temperature whereas its stability reduced with an increase in temperature. The FTIR studies showed that there were no drug-excipient interactions. The antiacne and anti-inflammatory activity showed an activity comparable to that of the standard drugs clindamycin and diclofenac, respectively. Hence it can be concluded that the formulation can be a good substitute for the existing synthetic anti-acne agents. 


\section{Cytotoxic activity $[14,18]$}

The ethyl acetate and n-hexane extracts of I. pes-tigridis were tested for Brine Shrimp Lethality Bioassay using brine shrimp naupli. The study showed that LC50 of the ethyl acetate and n-hexane extract is found to be $14.12 \mu \mathrm{g} / \mathrm{ml}$ and $33.13 \mu \mathrm{g} / \mathrm{ml}$ respectively. The study on ethanolic extract of $I$. pes-tigridis against HepG2 cell line (liver cancer cell line) showed that the extract has significant cytotoxic effect at the concentration of $500 \mu \mathrm{g} / \mathrm{ml}$ producing $99.87 \%$ cell inhibition.

\section{Thrombolytic activity [14]}

The ethyl acetate and n-hexane extracts of I. pes-tigridis leaves showed clot lytic activity in the controlled study conducted by in vitro method. The activity was much more significant for ethyl acetate extract than n-hexane extract.

Table 3: Ethanomedicinal values of ipomoea pes-tigridis [19-23]

\begin{tabular}{lll}
\hline S. No. & Medicinal uses and other characteristic studies & Study details \\
\hline 1 & Analgesic and neuropharmacological effect & In vivo study on Albino miceRamesh 2010; Chowdhury et al., 2014 \\
2 & Ethnopharmacognostical investigations & Plant taxanomy and histology studies Pratap et al., 2011 \\
3 & Cytotoxic activity against HepG2 cell line & In vitro cytotoxic studies against liver cancer cell line Begum et al., \\
& & 2015 \\
4 & Antimicrobial,Thrombolytic and Cytotoxic activity & In vitro studies on a plant leaf. Chowdhury et al., 2015 \\
5 & Nutritive value and digestibility studies & Meira et al., 2012 \\
6 & Leaves are used for poulticing sores and pimples & In vivo study. Quisumbing, 1951. \\
7 & Biochemical studies on Ipomoea pollen for understanding & Isozyme studies and Phylogenic mapping. Das and Mukherjee, \\
8 & species homology & 2015 \\
& Ethnopharmacognostical Investigation with characteristic & Pratap et al.,2011 \\
9. & taxonomical studies & \\
10 & Extract of the plant used in Snake bites & Chopra et al., 1956. \\
\end{tabular}

\section{CONCLUSION}

Ipomoea pes-tigridis $\mathrm{L}$. is one of the significant medicinal plants belonging to the family Convolvulaceae. The present review has brought out overall details of the Ipomoea pes-tigridis regarding its botanical characteristics, distribution, medicinal uses and the study was investigated the plant has the following phyto constituents is responsible for the following pharmacological activities. The presence of terpenoids in plants has shown to possess antimicrobial and antiinflammatory properties. Tannins in plants have also been suggested to possess potent antimicrobial activities. Anti-oxidant and antiinflammatory properties and wound healing property. Several alkaloids had been reported to possess antidiabetic effect. Saponins have also been indicated potent anti-microbial activity antioxidant activity anti-inflammatory activity, hypolipedemic activity, and haemolytic activity, cholesterol binding properties and bitterness. Studies showed that flavonoid and polyphenolic compound have shown to possess antioxidant and anti-inflammatory activity. Studies have revealed that triterpenoids have hypolipidemic activity.

\section{AUTHORS CONTRIBUTIONS}

All the author have contributed equally

\section{CONFLICT OF INTERESTS}

Declared none

\section{REFERENCES}

1. The Wealth of India, The dictionary of raw materials, CSIR. New Delhi. Vol. V. H-K; 1984. p. 251.

2. O' Brien TP, Feder N, McCull ME. Polychromatic staining of plant cell walls by toluidine blue-0. Protoplasma 1964;59:364-73.

3. Evan WC. Trease and evans pharmacognosy. 15 ${ }^{\text {th }}$ Edition. Saunders, London; 2002. p. 193, 230, 241, 336, 536.

4. www.flickr.com/photos/dinesh_valke/3975839631/ [Last accessed on 05 Jun 2018].

5. Matthew KM. The Flora of the Tamil Nadu Carnatic. Vol. 2; 1981. p. 1017-33.

6. Chopra RN, Nayar SL, Chopra IC. Glossary of Indian Medicinal Plants; 1956. p. 141-2.

7. Finar IL, Organic Chemistry. Vol. 2. ELBS, London. $5^{\text {th }}$ Edition; 1996. p. 71.

8. Chatwal GR. Organic Chemistry. $1^{\text {st }}$ edn. Himalaya Publishing Home, Mumbai; 2000. p. 2539.

9. Wadher SJ, Yeole PG, Gaikwad NJ. Pharmacognostical and phytochemical studies heartwood of Pterocarpus marsupium. Hamdard Med 2009;52:97-101.
10. Pratap GP, Sudarsanam G, Jyothi B, Prasad GP, David KM. Ethnopharmacognostical investigation on Ipomoea pes-tigridis linn. Int J Phytomed 2011;3:524-39.

11. Thamizh Selvam N. Physico-chemical, phytochemical and spectroscopic characterization of various extracts of leaves and stems of ipomoea pes-tigridis L. Adv Pharm J 2017;2:34-40.

12. Ramesh R. Analgesic effects of the aqueous extracts of plant Ipomoea pes-tigridis studied in albino mice. Global J Pharmacol 2010;4:31-5.

13. Chowdhury RH, Saha R, Minhazul Islam KM, Fatema K, Afrin F, Hossain MM. Analgesic and neuropharmacological effect of ethyl acetate extract of Ipomoea pes-tigridis in albino mice. Eur Sci J 2014;10:344-53.

14. Chowdhury RH, Saha R, Bhuiyan MI, Hossain MA, Kowsar SAM, Hossain MM. An in vitro assessment of antimicrobial, thrombolytic and cytotoxic activity on Ipomoea pes-tigridis. J Adv Med Life Sci 2014;2:1-8.

15. Braca A, Tommasi ND, Bari LD. Antioxidant principles from Bauhinia terapotensis. J Nat Prod 2001;64:892-5.

16. Kabir MSH, Hossain MM, Kabir MI, Ahmad S, Chakrabarty N, Rahman MA, et al. Antioxidant, antidiarrheal, hypoglycemic and thrombolytic activities of organic and aqueous extracts of Hopea odorata leaves and in silico PASS prediction of its isolated compounds. BMC Complementary Altern Med 2016;16:474.

17. Sandhya S, Vidhya Sravanthi E, David Banji, Rajeswar T. A review on medicinal herbs used for acne. Res J Topical Cosmetic Sci 2011;2:40-4.

18. Begum SS, Aruna A, Sivakumar T, Premanand C, Sribhuvaneswari C. In vitro cytotoxic activity on ethanolic extracts of leaves of Ipomoea pes-tigridis (Convolvulaceae) against liver Hep G2 cell line. Int J Ayurvedic Herbal Med 2015;5:1778-84.

19. Chopra RN, Nayer SL, Chopra IC. Glossary of Indian medicinal plants. CSIR. V Ed. New Delhi; 1956;12:157.

20. Diego Amor-Pratsa, Harbornea JB. New sources of ergoline alkaloids within the genus Ipomoea. Biochem Syst Ecol 1993;21:455-61.

21. Meira M, Silva EP, David JM, David JP. Review of the genus Ipomoea: traditional uses, chemistry and biological activities. Brazilian J Pharmacogn 2012;22:682-713.

22. Quisumbing EA. Medicinal plants of the philippines. Manila Publication. Philippines (Republic) Department of Agriculture and Natural Sources: Technical Bulletin; 1951.

23. Das S, Mukherjee KK. Biochemical studies on ipomoea pollen to understand species homology. Grana 1995;34:332-7. 